\title{
F100 ENGINE DIAGHOSTIC SYSTEM STATUS TO DATE
}

\author{
James A. Boyless \\ Wright-Patterson Air Force Base
}

SUMMARY

An engine diagnostic system, proposed for the Fl00 engine, is being tested in five specially modified Tactical Air Command F-15 aircraft during a 16 -month flight evaluation at Langley AFB, Virginia. After more than 3300 engine operating hours encompassing almost $900 \mathrm{flights}$ during the flight evaluation, these aircraft provided a data base, still being analyzed, that has shown successful demonstration of the original functional characteristics. Table $\mid A$ presents the general system evaluation in six areas while Table IB presents a more detailed look at these functional characteristics through March 81 . Those areas listed as partially demonstrated are now being further tested at Langley AFB. Four general design requirements; recording engine operating time/low cycle fatigue event detection, engine trim and trend and performance data collection were demonstrated. It also successfully demonstrated validation of maintenance actions taken and indicated needed maintenance.

\section{INTRODUCTION}

The U.S. Air Force On-Condition Maintenance (OCM) concept, defined in AF Regulation 66-14, directs maintenance on the basis that the condition of the equipment dictates the need for maintenance. To adequately perform OCM, inputs from engine maintenance management tools such as oil analysis, borescope inspection, parts tracking, periodic and phase inspection, monitoring, and diagnostics are required. Of these, monitoring and diagnostics are, by far, the most difficult to achieve. Monitoring and diagnostics development activities have encompassed aircraft/engine systems from the F100/J57 to the recent $\mathrm{F}-15 / \mathrm{F} 100$. On each system, various parameters, both airframe and engine, have been used to provide a sumrary of information for maintenance personnel, logistic support and provide a feedback loop for future engine development. A review of the F-15/F100 Engine Diagnostic System (EDS) through a system description and status to date is presented.

\section{BACKGROUND}

\section{HISTORY}

1. As gas turbine engine technology increased in complexity, so too, did the need to assist maintenance personnel to perform and diagnose problems for maintenance. In addition to assisting on-base maintenance through increased emphasis on On-Condition Maintenance, logistic requirements for improved engine life usage data dictated a means of acquiring that data be developed.

2. Preliminary studies by the Air Force Propulsion Laboratory indicated that an Advanced Fighter Diagnostic System (AFDS) could prove feasible in an 
application for an advanced design jet engine. The fFDS results led to definition of both hardware and software requirements as well as researching existing capabilities. Additional studies were then conducted to evaluate the significant areas of on-board processor, engine sensors, and use of existing equipment for system development. This system (renamed F100 Engine Diagnostic System (EDS)) was targeted for the F100 engine in both the F-15 and F-16 aircraft. These two aircraft powered by the same basic Pratt $\&$ Whitney F100, were chosen for the complexity and the operational environment envisioned for the engine.

\section{SYSTEM DESCRIPTION}

The Flo0 engine is well suited for the complex task of engine diagnostics. It is a modular engine designed for operational readiness and maintainability. It is also complex and requires knowledgeable maintenance personnel for repair. To ably assist the maintenance personnel, the FlO0 EDS went through an extensive review of Failure Modes and Effects Analysis (FEMA) and cost effective analysis. Thirty eight engine and airframe parameters were included in the EDS. Once these parameters were selected, hardware was developed to monitor the required information. The F100 EDS has eight primary elements that visually present cues of engine status, and/or provides a means to collect and diagnose engine anomalies. These elements shown in Figure 1 are:

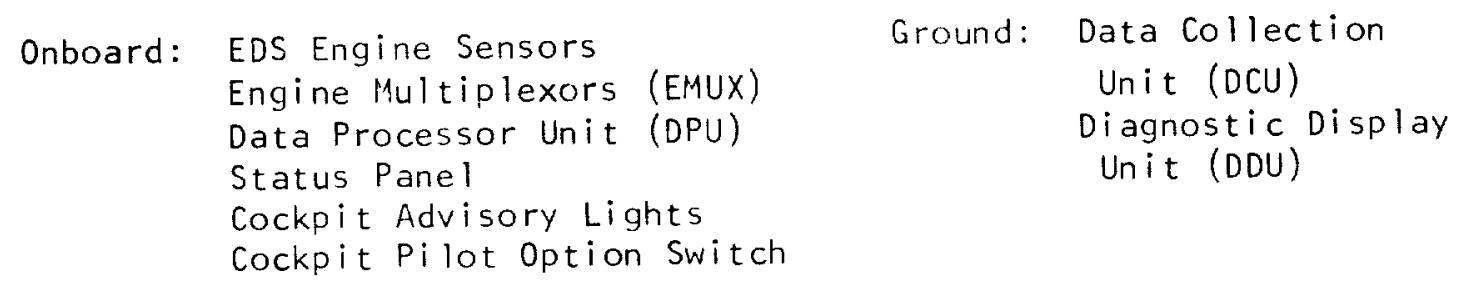

\section{ENGINE MULTIPLEXER (EMUX)}

The engine multiplexer unit was developed under Air Force contract to collect, condition and multiplex sensor signals serially to the onboard Data Processor Unit (DPU). The EMUX replaces both the present Flo0 Event History Recorder (EHR) and the junction box (J-BOx) for engine aircraft electrical connections. The unit is fuel cooled using existing EHR cooling lines and is hard mounted in the area vacated by the J-Box. EMUX reliability and durability to perform its functions is achieved through internal vibration isolation.

\section{DATA PROCESSOR UNIT (DPU)}

The DPU is an airframe mounted, air cooled unit consisting of a central processor, Intel 8080 , core memory, and interface circuits. Both cooling and electrical power requirements are provided by the aircraft. This unit is the nerve center of the inflight monitoring system. It is programed through software logic to detect a limit exceedance, declare an event, and store that event for later collection/diagnosis.

\section{AIRCRAFT COMPONENTS}

1. There are three aircraft components that are integral parts of the EDS; the cockpit warning lights and pilot option switch, status panel, and transfer 
receptacle. These components are also depicted in Figure 1. The DPU can, on command, store a data record by means of the pilot option switch located to the left of the pilot. In addition, a cockpit warning lights indicate Fan Turbine Inlet Temperature (FTIT) Overtemperature or excessive temperature occurrences.

2. To aid Flight Line personnel to quickly determine if an aircraft can be turned around, an EDS Status Panel is located in the existing maintenance access door, 48L. The status panel has latching indicators that can be set by either the DPU or EMUX. Either built-in-test for DPU and EMUX will set these latches as well as Hot Start detection for either engine.

3. The transfer receptacle, located in the same access door as the status panel quickly connects the DPU to either the DCU or DDU for extraction of stored data. Average transfer time is six seconds. Either collection or diagnostic operation can be performed under the "wing."

\section{DATA DIAGNOSTIC UNIT (DDU)}

Just as the DPU is the nerve center of the onboard system, the DDU serves that function on the ground. It is a portable ground unit with an alphanumeric display screen and keyboard for interfacing the maintenance personnel. For storage of flight data the DDU has the capability to maintain five records. The unit shares common components with the DPU for increased maintainability. The interface of maintenance personnel and the under the "wing" is accomplished by providing power through batteries. The unit can also be used with 115 volts $A C$ in test areas or engine shop.

\section{DATA COLLECTION UNIT (DCU)}

The DCU is small, light weight, and portable unit that uses internal battery power. It is used to collect and transfer data stored by the DPU. There are indicators for successful transfers of data from DPU and the presence of any maintenance advisory information. The DCU is designed to collect data from 10 to 15 aircraft and shares common modules with the DPU and DDU.

\section{SYSTEM CAPABILITIES}

The entire Engine Diagnostic System functional characteristics are designed to perform in five specific areas. These areas include Time and Cycle recording, Event Detection, Diagnostic and Troubleshooting, Engine Trim, and Trend $\varepsilon$ Performance data collection. A capsulized view of these capabilities vs either installed or uninstalled engine is shown in the following table:

FUNCTIONAL CAPABILITIES VS ENGINE INSTALLATION I NSTALLED UNINSTALLED

Time and cycle

Event Detection Diagnostic \& Troubleshooting Engine Trim Trend $\&$ Performance

$\begin{array}{ll}\text { DPU } & \text { DPU } \\ \text { DPU } & \text { DDU } \\ \text { DDU } & \text { DDU } \\ \text { DPU/DDU } & \text { DDU } \\ \text { DPU } & \end{array}$


A schematic view of how EDS data was collected is shown in Figure 2 . The components shown detail the units involved in the airborne and ground portions of the system description.

\section{FLIGHT EVALUATION}

\section{TEST ENVIRONMENT}

1. The test environment was a Tactical Air Command operational base, where the EDS was an adjunct to the existing base level maintenance organization. The base level maintenance organizations were involved throughout the Flight Evaluation Program (FEP) but the impact of EDS on maintenance was to be on a non-interference basis. This basis was justified in the fact that EDS was in a validation phase rather than actually being incorporated into the entire fleet.

2. Both test equipment, and Auxiliary Ground Processor (AGP) were procured and installed in the EDS Laboratory. Nine permanent party individuals were on-site during the FEP.

\section{TEST AIRCRAFT}

Five Tactical Air Command (TAC) F-15 (10 F100 Engines + one spare) were specially modified with EDS equipment. A control group of 12 non-EDS Fl00 engines were identified for comparison.

\section{TEST METHOD}

1. The objective of the test can be summed by Figure 3. The functional capabilities of the FIO0 EDS were to be validated through actual inflight collection, ground transfer, and on-site evaluation of data. As a basis for validation, 3000 engine operating hours was set as a goal. Furthermore, a detailed Flight Evaluation Plan (FEP) was used as a tool in evaluating the inflight data. Every diagnostic find was verified and validated by performance of a resulting maintenance action.

2. Time and cycle recording functional capability was to be accomplished automatically by the EDS. Transfer of the recorded data would take place from the DDU to a teletype in the proper format of the present AFTO form 93.

3. To accomplish the test method the present Maintenance Action Cycle used at Langley was to be integrated with the EDS. Figure 4 shows schematically how this occurred. During the test the crewchief would check the EDS status panel to determine aircraft availability. If any work would be needed the flight dispatcher would send a technician with the DDU or DCU. The DDU provided information would be reviewed by the propulsion maintenance unit with advice and/or assistance provided by the EDS team.

4. To gather the data, there were five $F-15$ aircraft and eleven engines specially modified for the test (See Figure 5). These aircraft were to average between 45 and 60 engine operating hours per month (See Figure 6). 
5. Validation of the data included an indepth critique of the inflight data. There were five categories in which the data were grouped. These groups include Hits, Goods, False $(I \& \mid I)$ and Misses. Hits would be scored as follows; An event was declared only by EDS and/or the event was confirmed by the present reporting system, a pilot or maintenance write up. A good is an event not declared by EDS nor reported by the present system. On the other hand, False 1 is an event declared by EDS and not by the system while False II is false but a known "fix" is in work to remedy the cause. Finally, a Miss is a pilot or maintenance write up not detected by EDS when it should have been.

6. Engine trim both installed and uninstalled would be performed in place of the present trim procedures using the present $M-37$ test stand. Careful monitoring of the time used to trim, and fuel used were recorded for comparison against non-EDS engines.

7. Diagnostics and troubleshooting was to be evaluated by careful review of actual usage of the equipment by the Maintenance personnel. If maintenance was declared once an event detection occurred, the procedure called for the repairman to use the DDU. Once validation of the event occurred, the DDU was to be used to diagnose or "troubleshoot" the malfunction. Maintenance records would be screened and data kept that expressed the amount of usage the DDU attained, time to troubleshoot, and diagnose malfunctions and compared to the control group.

8. Once the diagnostic and troubleshooting scenario ended and an Engine trim was required, the fourth capability was to be evaluated. In fact, this evaluation included all engines to be trimmed. Records were to be kept for manhours required to trim and fuel used.

9. Finally, the ability of the system to collect trend and performance data was to be tested.

\section{RESULTS AND DISCUSSION}

1. The Flight Evaluation Program (FEP) test results are presented in the succeeding figures. These results are based upon the period 1 Apr - 12 Dec 80 and the data gathered at Langley AFB, Virginia. The FEP, because of software complexity, was divided into a debug and actual validation period. Figure 7 gives a comparison of the actual vs projected engine operating hours. There were 2577 hours attained by 12 Dec 80 and an additional 738 hours through $26 \mathrm{Mar} 81$. Time and Cycle data was automatically printed by a printer to correspond with the actual AFTO Form 93 required by the engine management information system (see Figure 8 ). From the beginning of the program there were 13 events that were continuously monitored from start-up to shut-down of the engine. As the program progressed, however, there were lessons learned that deleted one event and switched four from No-Go to Maintenance Advisory. These four events are depicted in Table III. The system's ability to detect events accurately was extremely important. Figure 9, Event Detection Accuracy, shows how the accuracy of the system progressed. The check sum on the abcissa is an identity associated wi th software improvements of the basic event detection logic. As can be seen accuracy increased from a point of 88.7 percent to 99.7 percent at 12 Dec 80 . The 99.7 percent assessment is based upon 
77 transfers of data (See Figure 10) where 63 Hits were recorded. These Hits inturn were used to recommend maintenance action. There were 1006 goods reports with only 3 False I events detected.

2. These results demonstrate the successful capability of EDS to detect events. By using the last operable checksum, 0119 , the entire evaluation period was reviewed and summarized as shown in Table $V$. Of the twelve events, continuously monitored by EDS there were five events that were detected on numerous flights during the evaluation period. Three events clearly stand out. Stalls were very prevalent during the evaluation period. How extensive they are can only be speculated at the present time. Detailed analysis of this event continues.

3. Fan Turbine Inlet Temperatures (FTIT) Spread events were also numerous during the evaluation. These EDS modified engines have reported numerous FTIT Spread Events. Investigation continues to determine cause and effect on the engine. One attempt to seek information on effects has been to change borescope (Visual) inspection of the three engines to a 50 hour interval rather than the 100 hour interval presently used.

4. Just as Stalls and FTIT events have been prevalent, Rear Compressor Variable Vane (RCVV) events have also been numerous. These events have been tracked throughout the evaluation period. Investigation as to cause continues. Diagnostics and Troubleshooting capability have been demonstrated by EDS personnel in the laboratory and to a limited extent by maintenance personnel. Diagnostics and Troubleshooting by the EDS personnel throughout the evaluation period occurred on a daily basis to confirm detected events and recommend maintenance. Maintenance personnel used EDS in a limited manner as a maintenance tool as well as a training aid.

5. Tables $V, V I A$ and $B$ show the potential engine and maintenance saves credited to EDS during the flight evaluation. Engine saves included a high scavenge pressure event that the pilot was unaware of. Had the discrepancy continued the engine could have reached the catastrophic state of complete loss. The most obvious save for maintenance is preventing mis-directed maintenance. Four of the eight pilot assessments included dual engine anomalies whereas EDS confirmed only one engine had the anomaly not both.

6. EDS engine trim capability was demonstrated. Both uninstalled and installed engine trim was performed using EDS. After five partially successful attempts at uninstalled trim, identified software changes have been made and testing continues. Installed engine trim has been successfully demonstrated after several attempts. The entire trim procedure with exception of Engine Pressure Ratio (EPR) check was performed. EPR check could not be accomplished due to a false sensor reading.

7. Finally, trend and performance data was collected. Accumulated data indicates that 183 data points were captured EDS and the resulting analysis revealed that $74 \%$ of the data points lay in the lower PLA range (See Figure 11 ). This range, $30^{6}-40^{\circ}$, is the area of idle reset area where the augmentor is wide open. The conditions for data to accurately reflect trending and performance required a stabilization time of 180 seconds and was often reached in a landing 
approach. But due to the reprogramming ability of EDS a change of constants for PLA was approved and capture of data will be in the desired PLA range, $40-80^{\circ}$. 


\section{SYSTEM EVALUATION}

\section{SUMMARY}

- OVER 650 fLIGHT SETS Of DATA ANALYzed

- DEVISEDIIMPLEMENTED SOFTWARE DIAGNOSTIC TECHNIQUES

- evaluated 8 Sets of Software - 3 OfPs, 2 OdPs, 2 OCPs

- VALIDATED SYSTEMS CONTRIBUTION IN AREA OF

- ENGINE ANOMALIES

- maINTENANCE ACTIONS

- VALIDATED SYSTEMS ABILITY TO COLLECT DATA

- TIME/CYCLE

- PeRformancettRend

- DEMONSTRATED SYSTEM FLEXIBILITY THRU

AEPROGAAMMABILITY

TABLE IA

\section{CAPABILITIES \\ SUMMARY OF RESULTS}

(1 APR 80 - 26 MAR 81)

- DATA COLLECTION - $87 \%$ of flights RECORDED

- EVENT DETECTION - $99 \%$ aCCURATE

- data analysis - Demonstrated

- trim CaPABILITy . PARTIALLy deMONSTRATEO

- GROUND DIAGNOSTICS - DEMONSTRATED

- USER EVALUATION PARTIALLy DEMONSTRATED

- trend and performance - data collected

TABLE IB 


\section{EDS TOTAL SYSTEM DESIGN \\ FUNCTIONAL CHARACTERISTICS}

- DETECT EVENTS AND LIMIT EXCEEDANCES

- Collect in.Flight tREND data

- PaOVIDe in.Flight performance Check CAPABILITY

- aecord operating time and lCf counts

- PROVIDE "No.go" Indication at the flight line

- CONDUCT FAULT ISOLATION AND DEFINE MAINTENANCE ACTIONS

- PROVIDE HARD COPY OF ENGINE RECORDS FOR INPUT INTO CENTRAL DATA SYSTEMS

- Provide Capability to performance engine trim

TABLE II

\section{EVENT MENU}

\begin{tabular}{|c|c|c|c|c|}
\hline \multirow[b]{2}{*}{ EVEMT TYPES } & \multicolumn{2}{|c|}{$\begin{array}{c}\text { AT STAAT OF } \\
\text { FLLGT PROGAAM } \\
\text { IJ EVEMTS (II MOGO) }\end{array}$} & \multicolumn{2}{|c|}{$\begin{array}{c}\text { AT END OF } \\
\text { FLIGHT PROGRAM } \\
\text { I2 EVENTS (S MO-GO) } \\
\end{array}$} \\
\hline & M0.60 & $\begin{array}{c}\text { MAIMTENANCE } \\
\text { ADVISOAY } \\
\end{array}$ & NO-GO & $\begin{array}{c}\text { MAINTEMAMCE } \\
\text { ADVISORY }\end{array}$ \\
\hline HOT START & $x$ & - & $x$ & - \\
\hline $\mathrm{N}_{2}$ OVERSPEED & $x$ & - & $x$ & - \\
\hline FTIT OVERTEMP & $\mathbf{x}$ & - & $x$ & - \\
\hline FTIT SPAEAD OUT OF LIMITS & $x$ & - & - & 1 \\
\hline OIL PRESSURE OUT OF LIMITS & $\mathbf{x}$ & - & $x$ & - \\
\hline SCAVEMGE PRESSUAE OVER LIMITS & $x$ & - & - & 1 \\
\hline VIARATION OVEA LIMITS & $x$ & - & - & 1 \\
\hline EEC FAULT & $x$ & $\times \hat{\jmath}$ & $x$ & 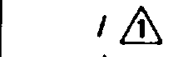 \\
\hline EMGIME STALL & $x$ & $\times 2$ & - & 1 \\
\hline AUGMENTOA BLOW.OUT MISLIGHT & $x$ & $x \leqslant 2$ & - & 1 \\
\hline RCVY OUT OF LAMITS & - & $x$ & - & 1 \\
\hline MAIN FUEL PUIMP DETERIORATION & - & $x$ & - & - \\
\hline MAIM FUEL PUMP FAILURE & $\mathbf{x}$ & - & $x$ & - \\
\hline
\end{tabular}

¿1 If cleared by pilot 2 if out of envelope 


\section{EVENTS* (HITS) DETECTED PER ENGINE \\ 10 JULY THRU 18 DECEMBER}

\begin{tabular}{|c|c|c|c|c|c|c|c|c|c|c|c|c|c|}
\hline & & \multicolumn{11}{|c|}{ ENGINE S/N } & \multirow{2}{*}{ TOTALS } \\
\hline & & 160 & 311 & 330 & 415 & 470 & 528 & 639 & 694 & 722 & 801 & 907 & \\
\hline $\begin{array}{l}\text { ENGINE } \\
\text { NO.GO }\end{array}$ & $\begin{array}{l}\text { HOT STAAT } \\
\text { O'SPEED } \\
\text { O'TEMP } \\
\text { OIL PAESS. } \\
\text { EEC } \\
\text { MFP FAIL } \\
\end{array}$ & $\begin{array}{l}1 \\
4\end{array}$ & & $\begin{array}{l}1 \\
7\end{array}$ & & 2 & $\begin{array}{l}2 \\
8\end{array}$ & & 1 & 1 & & 1 & $\begin{array}{c}2 \\
0 \\
2 \\
4 \\
24 \\
0\end{array}$ \\
\hline $\begin{array}{l}\text { MAINTENANCE } \\
\text { ADVISORY }\end{array}$ & $\begin{array}{l}\text { STALL } \\
\text { SPAEAD } \\
\text { SCAV PRESS. } \\
\text { AUG BO/ML. } \\
\text { RCVV } \\
\text { VIBS }\end{array}$ & 23 & $\begin{array}{l}22 \\
5 \\
4\end{array}$ & $\begin{array}{c}1 \\
38 \\
1 \\
19\end{array}$ & 3 & $\begin{array}{c}1 \\
9 \\
2 \\
13\end{array}$ & $\begin{array}{l}11 \\
1 \\
3 \\
4\end{array}$ & $\begin{array}{l}2 \\
1\end{array}$ & $\begin{array}{l}3 \\
1\end{array}$ & 3 & & $\begin{array}{c}16 \\
1\end{array}$ & $\begin{array}{c}21 \\
85 \\
9 \\
2 \\
46 \\
42\end{array}$ \\
\hline RECORDS & $\begin{array}{l}\text { TREND } \\
\text { PERF }\end{array}$ & $\begin{array}{r}16 \\
3\end{array}$ & $\begin{array}{r}15 \\
3\end{array}$ & $\begin{array}{l}29 \\
17\end{array}$ & $\begin{array}{l}9 \\
4\end{array}$ & $\begin{array}{c}17 \\
3\end{array}$ & $\begin{array}{l}9 \\
2\end{array}$ & $\begin{array}{c}24 \\
6\end{array}$ & $\begin{array}{l}27 \\
10\end{array}$ & $\begin{array}{l}18 \\
12\end{array}$ & $\begin{array}{l}6 \\
4\end{array}$ & $\begin{array}{c}13 \\
3\end{array}$ & $\begin{array}{c}183 \\
67\end{array}$ \\
\hline
\end{tabular}

-Hits - as determined by checksum 0119 in use at the end of the program

TABLE IV

\section{POTENTIAL ENGINE “SAVES” BY EDS}

\begin{tabular}{|c|c|c|c|}
\hline EVENT. & $\begin{array}{c}\text { ENGINE } \\
\text { S/N }\end{array}$ & $\begin{array}{c}\text { PILOT } \\
\text { REPORTED }\end{array}$ & CORAECTIVE ACTION \\
\hline OIL PRESS, LOW & 311 & YES & SERVICED OIL TANK \\
\hline SCAV PRESS., HI & 470 & NO & $\begin{array}{l}\text { VAC CHECK NO. } 4 \text { COMPARTMENT. } \\
\text { FOUND FOREIGN MATERIAL IN } \\
\text { ENGINE OIL SYSTEM. }\end{array}$ \\
\hline O'TEMP & 330 & YES & $\begin{array}{l}\text { EDS DETECTED O'TEMP LEVEL } \\
\text { HIGHER THAN AEPOATED BY THE } \\
\text { PILOT. EEC CHANGED. }\end{array}$ \\
\hline FTIT SPREAD & $\begin{array}{l}160 \\
311 \\
330\end{array}$ & $\begin{array}{l}\text { YES* } \\
\text { YES* } \\
\text { YES* }\end{array}$ & $\begin{array}{l}\text { BORESCOPE EVERY } 50 \text { FLIGHT } \\
\text { HOURS AS A PRECAUTION UNTIL } \\
\text { PHENOMENONANDCONSEOUENCES } \\
\text { CAN BE QUANTIFIED. }\end{array}$ \\
\hline $\begin{array}{l}\text { FAILED } \\
\text { FTIT PROBE }\end{array}$ & $\begin{array}{l}311 \\
694 \\
694 \\
\end{array}$ & $\begin{array}{l}\text { N.A. } \\
\text { N.A. } \\
\text { N.A. }\end{array}$ & $\begin{array}{l}\text { REPLACED NO. } 4 \text { PROBE, VERIFIED } \\
\text { REPLACED NO. } 4 \text { PROBE, VERIFIED } \\
\text { AEPLACED NO. } 5 \text { PROBE, VERIFIED }\end{array}$ \\
\hline $\begin{array}{l}\text { FAILED COCKPIT } \\
\text { WARNING LIGHT }\end{array}$ & & NO & $\begin{array}{l}\text { NON BILL OF MATERIAL RELAY } \\
\text { PANEL BLOCKED AN EEC FAILURE } \\
\text { WARNING TO COCKPIT. }\end{array}$ \\
\hline
\end{tabular}

"FTIT Spread is not monitored in aircraft other than EDS equipped aircraft. 


\section{MAINTENANCE “SAVES” BY EDS}

\begin{tabular}{|c|c|c|}
\hline $\begin{array}{l}\text { ENGINE } \\
\text { S/N }\end{array}$ & PILOT ASSESSMENT & EDS RECORD \\
\hline 694 & $\begin{array}{l}\text { HAVE TO MISMATCH } \\
\text { THAOTTLES TO MATCH } \\
\text { RPM }\end{array}$ & $\begin{array}{l}\text { PILOT OPTION DATA RECORD } \\
\text { CONFIRMED MISMATCH IN } \\
\text { RPM, FTIT. PLA RIGGING. }\end{array}$ \\
\hline 470 & NO COMPLAINTS & $\begin{array}{l}\text { REPEATED EEC LEVEL } 1 \\
\text { FAULTS. ODU CABLE SHOATED. }\end{array}$ \\
\hline 639 & NOT APPLICABLE & $\begin{array}{l}\text { SEVERAL FALSE RCVV EVENTS } \\
\text { ON RECENT FLIGHTS, TT2.5 } \\
\text { ERROR. MISSING AP2 PLUG. }\end{array}$ \\
\hline 722 & $\begin{array}{l}\text { LOW THRUST RPM } \\
\text { IN STABILITY }\end{array}$ & $\begin{array}{l}\text { LOW OUT OF TRIM, } \\
\text { PILOT OPTION RECORD. }\end{array}$ \\
\hline $\begin{array}{c}801 \\
(528)\end{array}$ & $\begin{array}{l}\text { A/B BLOWOUT ON BOTH } \\
\text { ENGINES (528/B01) }\end{array}$ & $\begin{array}{l}\text { NOTHING WRONG WITH } 801 . \\
\text { ENGINE S/N } 528 \text { HAD A “HARD } \\
\text { LIGHT/BLOWOUT" FOLLOWED } \\
\text { BY A STALL. EPR HIGH 0.11. }\end{array}$ \\
\hline
\end{tabular}

\section{MAINTENANCE “SAVES” BY EDS}

\begin{tabular}{|c|c|c|}
\hline $\begin{array}{l}\text { ENGINE } \\
\text { S/N }\end{array}$ & PILOT ASSESSMENT & EDS RECORD \\
\hline 311 & $\begin{array}{l}\text { A/B BLOWOUT ON 311, TOOK } \\
\text { PILOT OPTION. }\end{array}$ & $\begin{array}{l}\text { STALL FOLLOWING AN } \\
\text { AUGMENTOR "HARD LIGHT/ } \\
\text { BLOWOUT." RCVY's DUT OF } \\
\text { BAND, AXIAL ON STALL, RCVY } \\
\text { AND PILOT OPTION EVENTS. }\end{array}$ \\
\hline $\begin{array}{c}907 \\
(528)\end{array}$ & $\begin{array}{l}\text { A/B BLOWOUT ON BOTH } \\
\text { ENGINES (907/528). }\end{array}$ & $\begin{array}{l}\text { NOTHING WRONG WITH } 907 . \\
\text { ENGINE S/N } 528 \text { HAD A } \\
\text { "HARD LIGHT/BLOWOUT" } \\
\text { FOLLOWED BY A STALL. }\end{array}$ \\
\hline 722 & $\begin{array}{l}\text { PILOT REPORTED AUGMENTOR } \\
\text { ANOMALIES ON THAEE FLIGHTS. } \\
\text { ON SECOND FLIGHT DOUBLE } \\
\text { HARD LITE ON BUANERS. }\end{array}$ & $\begin{array}{l}\text { EDS DETECTED STALLS IN } \\
\text { AUGMENTATION ON EACH OF } \\
\text { THE THREE FLIGHTS FOA } \\
\text { ENGINE S/N } 722 \text { ONLY. }\end{array}$ \\
\hline
\end{tabular}




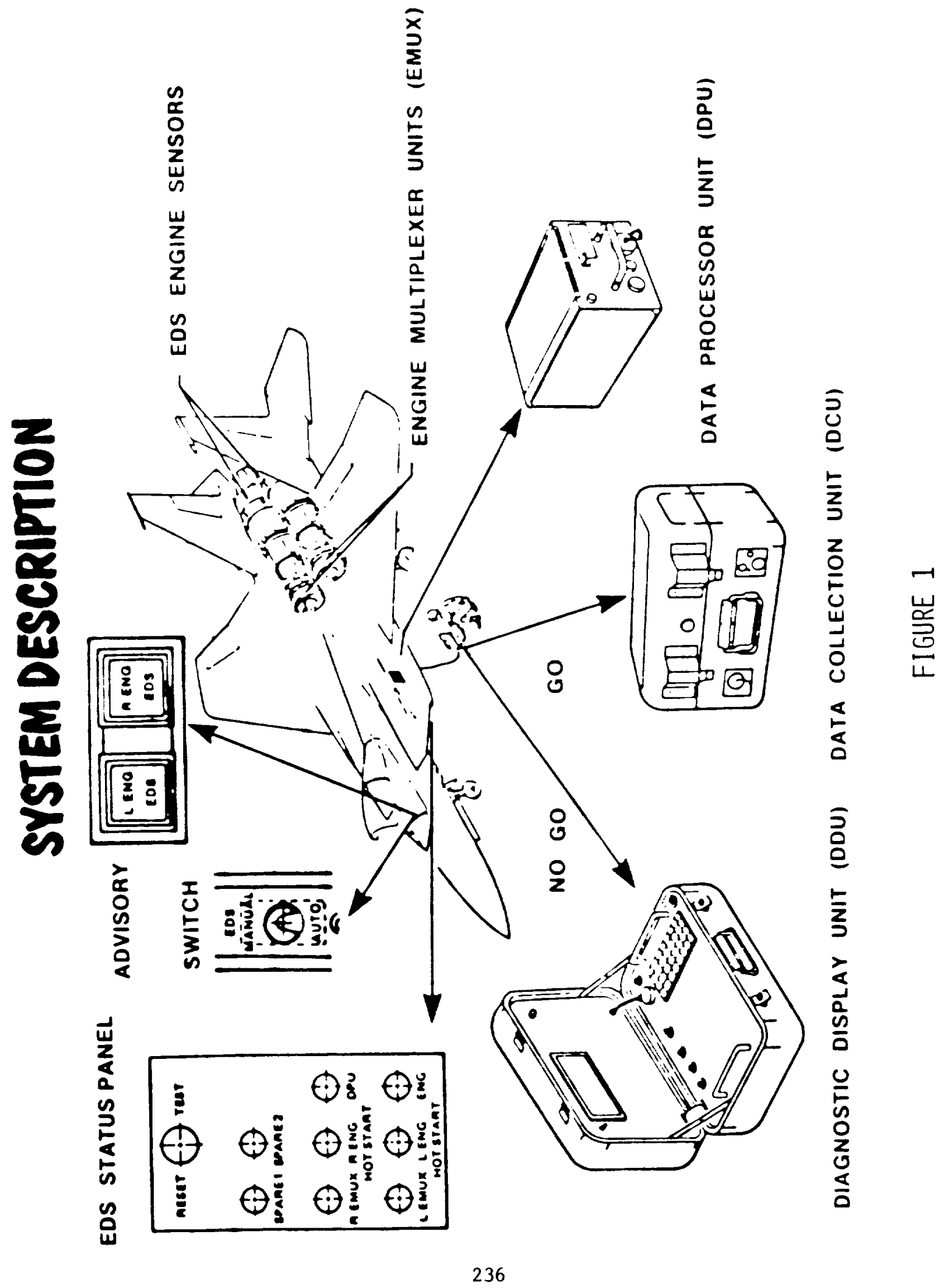




\section{EDS DATA COLLECTION}

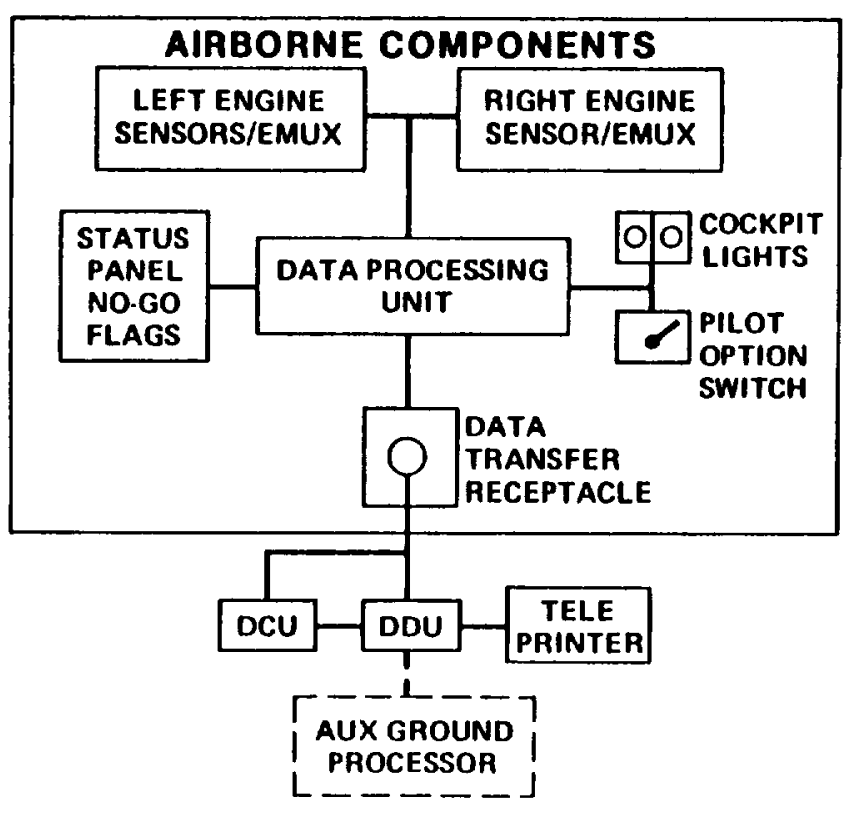

FIGURE 2

\section{OBJECTIVE}

- OVERALl

- VALIDATE SYSTEM CONCEPT, DESIGN, AND CAPABILITIES 


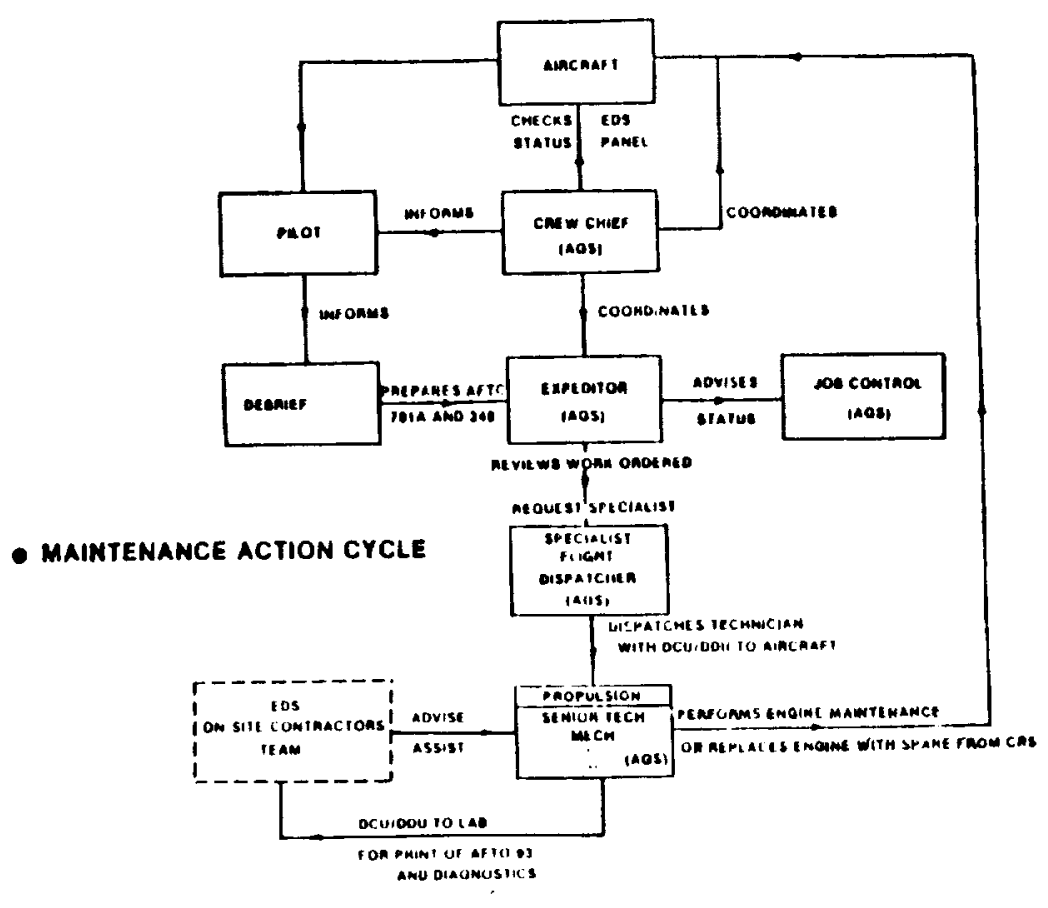

FIGURE 4

\section{METHOD \\ AIRCRATT/ENGINE ASSIGNMENT}

AIRCRAFT (5)
$74 \cdot 099$
$74 \cdot 103$
$74 \cdot 105$
$74 \cdot 107$
$74 \cdot 108$
F100 ENGINES (11)
PW E680160 PW E680639
PW E680311
PW E680694
PW E680330 PW E680722
PW E680415 PW E680001
PW E680470 PW E680907
PW E680528

FIGURE 5 


\section{EDS EXPECTED FLIGHT EVAL}

ENGINE OPERATING HOURS

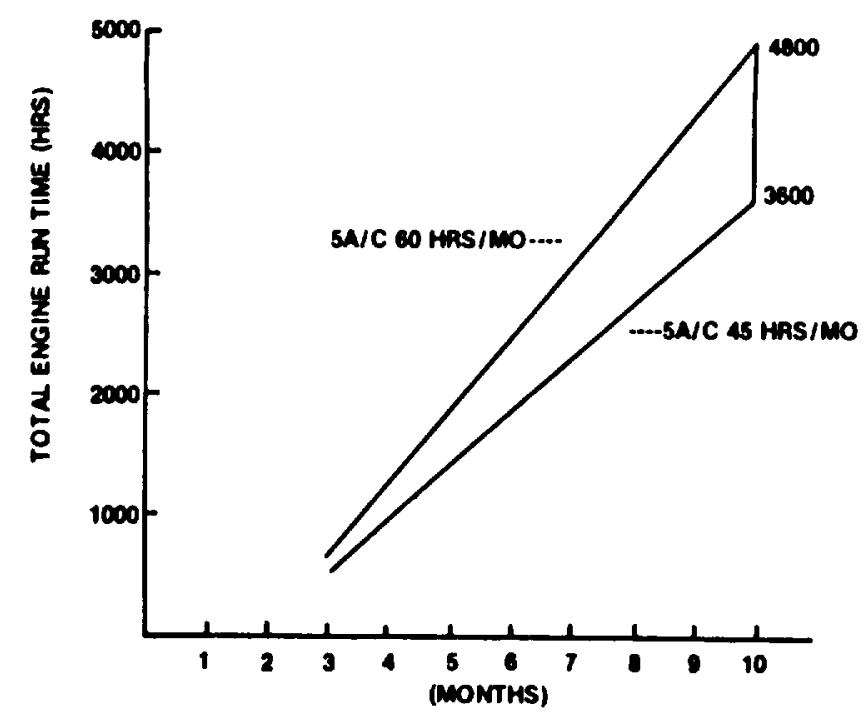

FIGURE 6

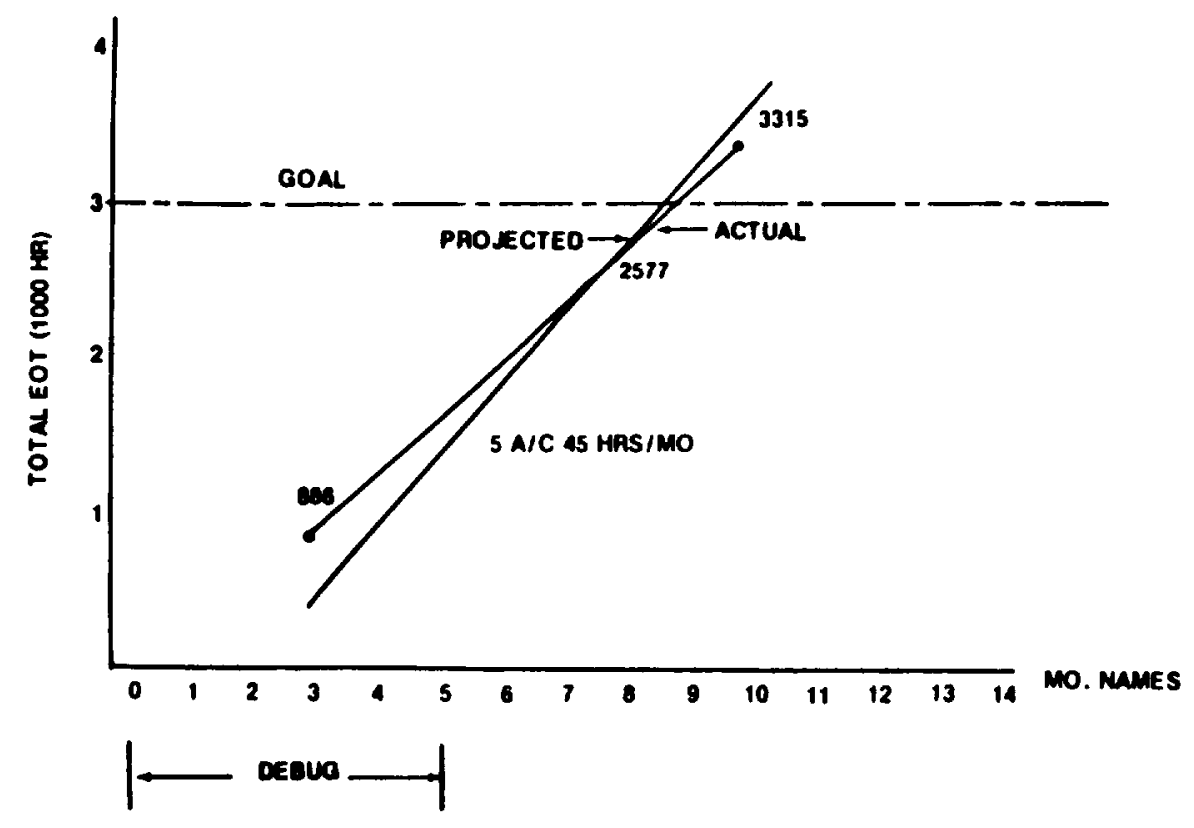

FIGURE 7 

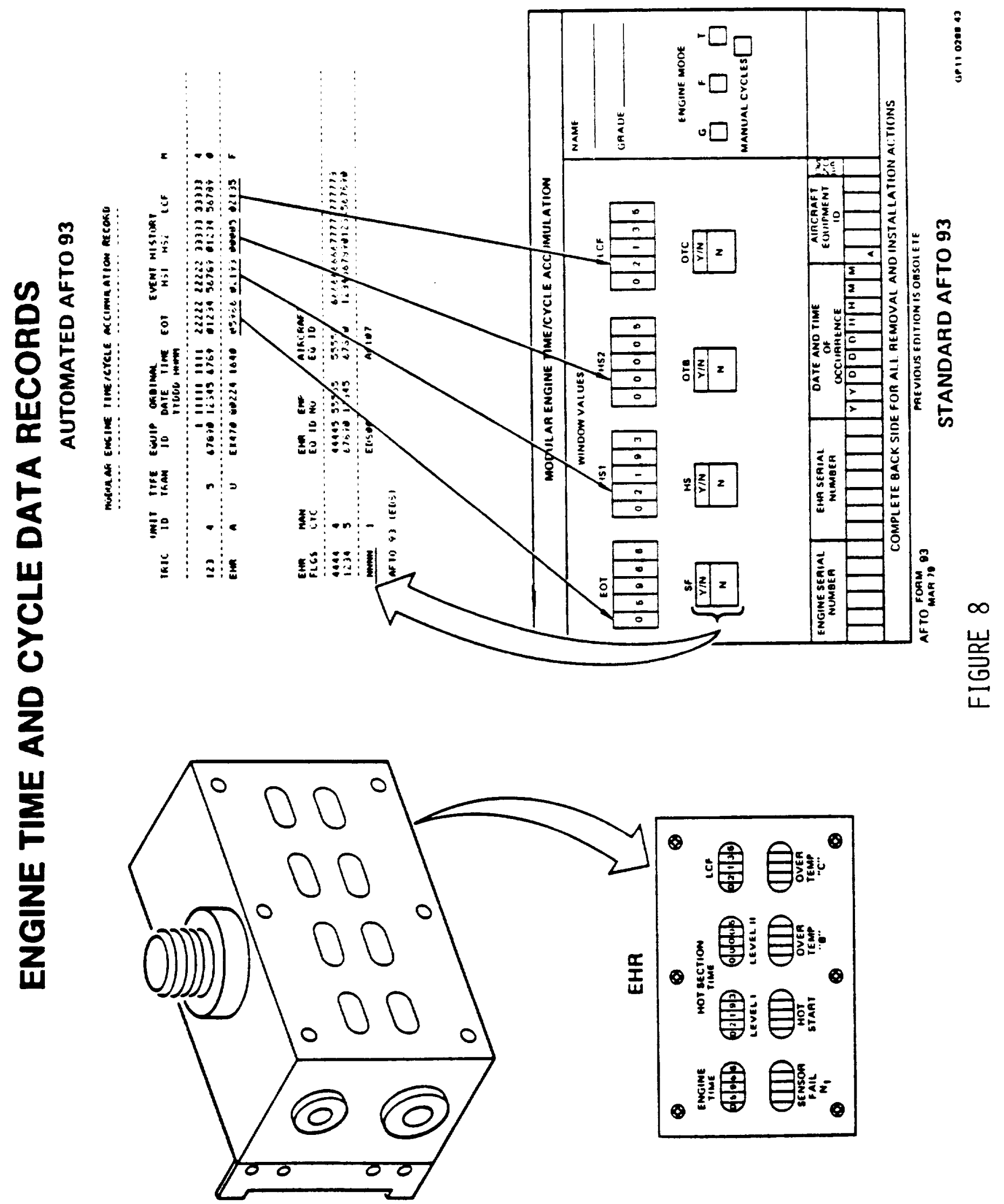


\section{EVENT DETECTION ACCURACY}

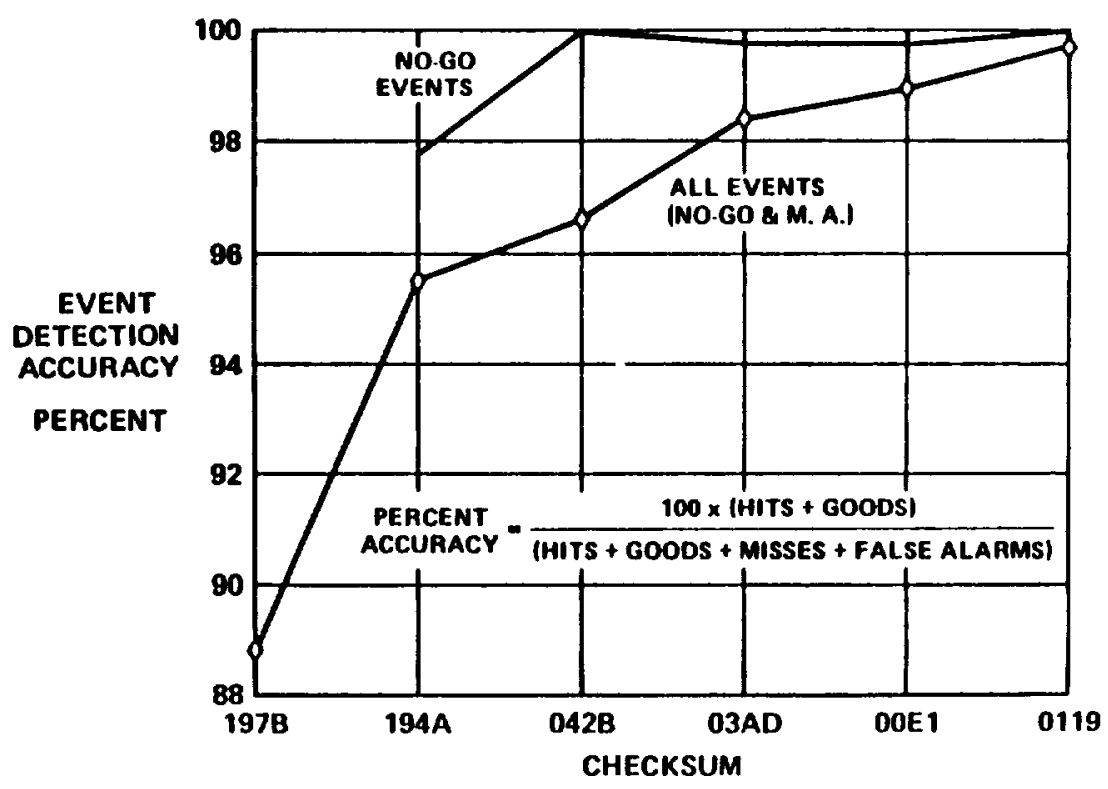

FIGURE 9

\section{SUMMARY OF}

EENTS DETECTED

(MRRU DEC 20)

\begin{tabular}{|c|c|c|c|c|c|c|}
\hline & MTS & Doons & FALSE ॥ & FALSE I & MISSES & ACCUAACY $\times$ \\
\hline TOTM & $\infty$ & 1000 & - & 3 & 0 & 09.7 \\
\hline
\end{tabular}

FIGURE 10 


\section{TREND/PEAFORMANCE RECORD SUMMARY}

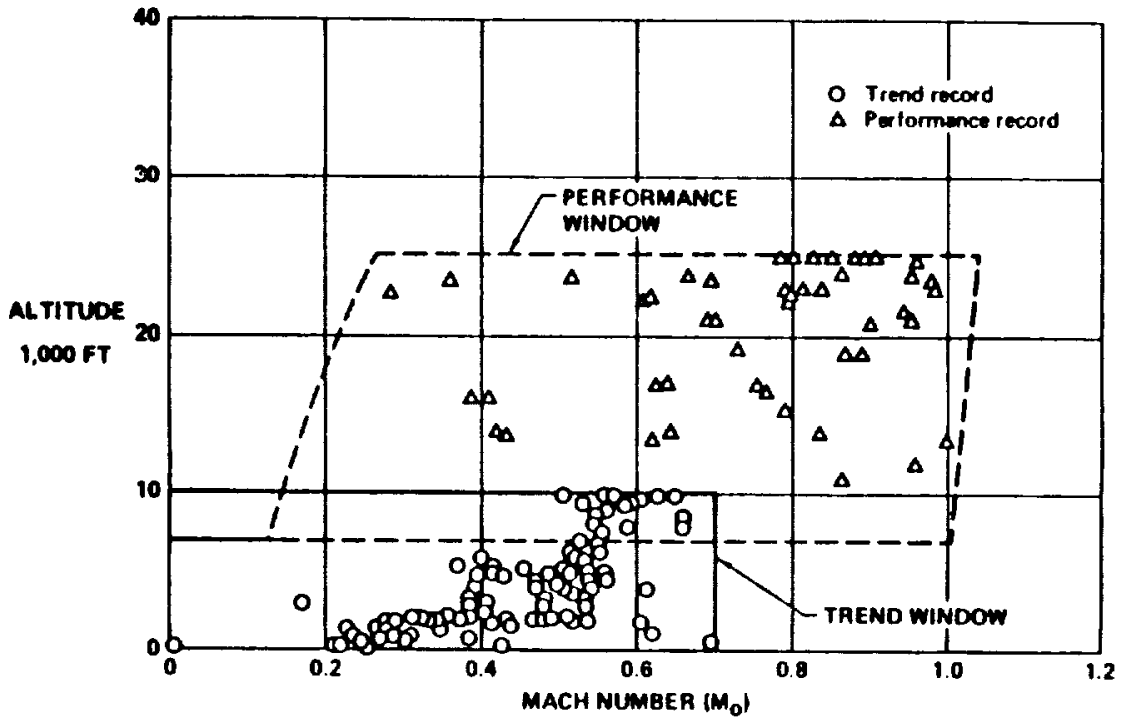

FIGURE 11 